\title{
Homeroom Teacher Strategy in Improving Learning Media Literacy during Covid-19 Pandemic
}

\section{Strategi Guru Kelas dalam Meningkatkan Literasi Media Pembelajaran di Masa Pandemi Covid-19}

\author{
Muhamad Arif ${ }^{1}$, Kusnul Munfa' ati², Mei Kalimatusyaroh ${ }^{3}$ \\ 1STAI Al-Azhar Menganti Gresik, ²UIN Sunan Ampel Surabaya, ${ }^{3}$ IAI Al-khoziny \\ Sidoarjo \\ e-mail: ${ }^{1}$ muhamadarif070593@gmail.com, 2mun.faati@gmail.com, \\ 3fasya.azzahro@gmail.com
}

\section{DOI: 10.18860/mad.v13i2.11804}

Abstract. The existence of the Covid-19 pandemic requires that all elements change from the economy, health and education. The role of teachers in education is the main key to successful learning. However, during the Covid-19 pandemic, online-based learning made teachers learn to improve learning media literacy, so that they could provide solutions to a fun learning process. In this research, we want to find answers about how homeroom teachers' strategies in increasing media literacy during the Covid-19 pandemic. This research used a qualitative method with a case study approach. The primary data source for the researcher was all class teachers in both Madrasah Ibtidaiyah. Collecting data using three techniques, observation, interviews and documentation. Analysis of the research data using the analysis of Miles and Huberman. Combined with the Quin Patton data validity test, namely data triangulation. The results showed that Madrasah Ibtidaiyah Al-Azhar Menganti Gresik increased media literacy individually and institutionally. Meanwhile, Madrasah Ibtidaiyah An-Nur Junwangi Sidoarjo individually. For homeroom teacher, learning media at Madrasah Ibtidaiyah Al-Azhar Changing Gresik Zoom, Google Meet, Canva, Youtube and Whatsapp media. Meanwhile, in Madrasah Ibtidaiyah An-Nur Junwangi Sidoarjo, the learning process still focused on using the Whatsapp Group. In addition, there are obstacles for classroom teachers in improving learning media literacy, including lack of internet quota, and infrastructure.

Keywords. Media Literacy; Homeroom Teacher; Covid-19

\begin{abstract}
Abstrak. Keberadaan pandemi Covid-19 mengharuskan seluruh elemen berubah mulai dari ekonomi, kesehatan serta dunia pendidikan. Peran guru dalam pendidikan menjadi kunci utama keberhasilan pembelajaran, namun, pada masa pendemi Covid-19 pembelajaran berbasis online menjadikan guru harus belajar untuk meningkatkan literasi media pembelajaran, sehingga dapat memberikan solusi pada proses pembelajaran yang menyenangkan. Pada riset ini ingin mencari jawaban tentang bagaimana strategi guru kelas dalam meningkatkan literasi media di masa pandemic covid-19. Riset ini menggunakan metode kualitatif pendekatan studi kasus, sumber data primer peneliti adalah seluruh guru kelas di kedua Madrasah Ibtidaiyah. Pengambilan data menggunakan tiga teknik, observasi, wawancara dan dokumentasi.
\end{abstract}

Vol. 13 No. 2 Juni 2021

Madrasah homepage: http://ejournal.uin-malang.ac.id/index.php/Madrasah/index 
Analisis data penelitian ini menggunakan analisis Miles dan Huberman. Dipadukan dengan uji keabsahan data Quin Patton yaitu triangulasi data. Hasil penelitian menunjukkan bahwa Madrasah Ibtidaiyah Al-Azhar Menganti Gresik, meningkatkan literasi media secara individu dan kelembagaan. Sedangkan Madrasah Ibtidaiyah AnNur Junwangi Sidoarjo secara individu. Untuk media pembelajaran guru kelas di Madrasah Ibtidaiyah Al-Azhar Menganti Gresik Zoom, Google Meet, Canva, media Youtube dan Whatsapp. Sedangkan di Madrasah Ibtidaiyah An-Nur Junwangi Sidoarjo dalam melaksanakan pembelajaran masih terfokus menggunakan Whatsapp Group. Selain itu terdapat Kendala guru kelas dalam meningkatkan literasi media pembelajaran meliputi: minimnya kuota internet, dan sarana prasarana.

Kata kunci. Literasi Media; Guru Kelas; Covid-19

Received: 06-03-2021

Revised: 22-04-2021
Approved: 28-04-2021

Published: 01-05-2021

Copyright (C) Madrasah Jurnal Pendidikan dan Pembelajaran Dasar. All Right Reserved. This is an open access article under the CC BY-SA license (Creative Commons Attribution-ShareAlike 4.0 International License.)

Correspondence Address: muhamadarif070593@gmail.com

\section{A. PENDAHULUAN}

Pendidikan pada dasarnya menjadi sebuah proses awal dalam mengembangkan kemampuan, sikap, prilaku dan kode etik yang berada pada ruang lingkup masyarakat (Nugraha et al., 2020, p. 10). Berkembangnya dunia teknologi memberikan pengaruh yang nyata pada dunia pendidikan. Sehingga mulai dari perilaku individu, sarana kehidupan dan tata nilai pada masyarakat mengalami perubahan. Berawal dari sini maka diperlukan adanya terobosan dalam dunia pendidikan, yang mendapatkan imbas langsung yaitu seorang pendidik, pendidik mempunyai kewajiban dalam melakukan transfer pengetahuan kepada peserta didik menggunakan inovasi dalam setiap pembelajaran (Malawi et al., 2018, p. 17).

Dunia teknologi dalam pendidikan semakin menjadi kebutuhan yang tidak dapat ditinggalkan, berawal dari adanya pandemi Covid-19, sebuah virus yang menyerang ribuan manusia di dunia tanpa memandang ras dan suku tertentu. Seperti keberadaan proses pembelajaran pada dunia pendidikan di masa pandemi Covid-19, yang mengalami perubahan signifikan, karena sebelum pandemi seluruh proses pembelajaran dilakukan dengan tatap muka, selama pandemi Covid-9 seluruh pembelajaran dilakukan dengan offline (belajar dari rumah) maka guru diharuskan mampu memanfaatkan teknologi secara maksimal (Pakpahan \& Fitriani, 2020). Posisi guru menjadi pemegang tongkat kendali terbesar dalam setiap proses pembelajaran, sebagimana kewajiban seorang guru untuk meningkatkan kompetensinya (Arif et al., 2020).

Salah satu kompetensi guru yang perlu ditingkatkan pada proses pembelajaran di tengah pendemi Covid-19 adalah kompetensi pedagogik. Pemilihan kompetensi pedagogik didasarkan pada salah satu indikator yang menyebutkan bahwa perlunya

Vol. 13 No. 2 Juni 2021

Madrasah homepage: http://ejournal.uin-malang.ac.id/index.php/Madrasah/index 
seorang guru dalam memilih media pembelajaran yang tepat serta membangun sistem pengetahuan yang konstruktif, kolaboratif serta mampu memanfaatkan potensi pada lingkungan sekitar (Korhonen et al., 2018). Sehingga literasi media bagi guru pada pembelajaran jarak jauh tidak bisa di tawar. Selain itu, keberadaan siswa dalam proses pembelajaran jarak jauh, memerlukan inovasi-inovasi media yang menyenangkan. Hal ini juga disampaikan Hurlbut dalam risetnya menyatakan bahwa pembelajaran online, memiliki peminat yang lebih banyak dari pada pembelajaran tradisional. Sehingga Siswa lebih mampu mengekplorasi kemampuannya secara bebas dan berkolaborasi dengan berbagai media teknologi yang berkembang di zamannya tanpa terkotak dengan pembelajaran di dalam ruangan yang di dalamnya hanya berkolaborasi dengan papan tulis (Hurlbut, 2018).

Pandemi Covid-19 membuat seluruh aspek pendidikan berubah secara signifikan, beberapa hasil riset juga memaparkan secara tepat tentang beberapa dampak yang terjadi. Seperti hasil riset Syah Aji tentang dampak Covid-19 pada dunia pendidikan di Indonesia, terutama yang berdampak pada kerugian siswa dalam hasil pembelajaran dan pada lulusannya. Syah Aji dalam risetnya menjelaskan strategi yang harus di benahi dalam proses pendidikan salah satunya adalah peran seorang guru sebagai garda terdepan dalam memberikan pembelajaran kepada siswa yang berupa ilmu dan tauladan, maka guru harus benar-benar mampu memaksimalkan kompetensinya dalam pembelajaran di tengah pandemi Covid-19 (Syah, 2020).

Dampak Covid-19 memang mengalami banyak dinamika dalam pembelajaran. Hal ini disampaikan Mansyur bahwa dinamika pembelajaran di Indonesia berubah signifikan, mulai dari pembelajaran yang terfokus di rumah (online), pemilihan media pembelajaran yang cukup bervariasi dalam dunia teknologi serta keharusan menjalin kolaborasi dengan orang tua. Mansyur juga memberikan garis besar dalam risetnya yaitu pada sosok guru yang mempunyai peran dalam mencapai keberhasilan dari tujuan pembelajaran (Mansyur, 2020). Keberadaan guru diharuskan dapat menyampaikan pembelajaran secara maksimal meskipun tanpa melalui tatap muka. Pada posisi ini, teknologi menjadi penting untuk diterapkan pada dunia pendidikan. Beberapa riset dalam dunia internasional menjadi sebuah rujukan dalam memanfaatkan teknologi. Nanda Dabbagh menjelaskan tentang posisi guru dalam memenuhi kewajibannya pada dunia pendidikan di era teknologi informasi, karena posisi teknologi yang semakin beragam dan berkembang sangat pesat, mulai dari teknologi berbasis website hingga peran media sosial dalam pembelajaran (Dabbagh, 2003).

Sijia Xue, dkk, menjelaskan bahwa posisi seorang guru seharusnya tidak hanya mengembangkan profesionalnya, melainkan guru di tuntut merubah praktik pengajaran dengan memanfaatkan teknologi yang berkembang. Xue dalam risetnya menggunakan proses pembelajaran berbasis media sosial yaitu transformasi OcoPs dengan WeChat. Hal ini untuk membiasakan guru dalam melakukan proses pembelajaran yang efisien terutama dalam pandemi Covid-19. Maka, perlu adanya klasifikasi dari guru berpengalaman dan guru pemula dalam pengembangan pengetahuan profesional guru berbasis pemanfaatan media teknologi pembelajaran di era pandemi Covid-19 (Xue, 2019). Hal ini juga disampaikan oleh Kim tentang penerapan media belajar berbasis pemanfaatan teknologi, para guru di Amerika Serikat, pada era pendemi Covid-19 berusaha secara maksimal mempromosikan

Vol. 13 No. 2 Juni 2021

Madrasah homepage: http://ejournal.uin-malang.ac.id/index.php/Madrasah/index 
pembelajaran berbasis teknologi informasi, mulai dari proses perencanaan, pelaksanaan, evaluasi, serta didukung dengan kreativitas dan pemikiran kritis. Maka, peningkatan pembelajaran berbasis pemanfaatan teknologi mutlak harus dimiliki guru (Kim, 2020). Sebagaiamana hasil penelitian Haqien menjelaskan bahwa aplikasi Zoom menjadi salah satu tawaran media yang banyak digunakan terlebih Zoom mempunyai fitur-fitur yang cukup lengkap, sehingga memudahkan pendidik dalam menyampaikan materi pembelajaran (Haqien \& Rahman, 2020).

Berdasarkan berbagai literatur review, tentang keberadaan pandemi Covid-19 yang mengharuskan seluruh elemen berubah, sehingga peneliti menemukan satu ruang kosong yang masih perlu dilakukan diskusi melalui riset spesifik, yaitu tentang keberadaan guru yang secara langsung berdampak sehingga harus meningkatkan pengetahuan tentang literasi media secara maksimal. Terutama posisi guru pada pendidikan dasar sebagai guru kelas dengan beban tugas mengampu mata pelajaran tematik. Beberapa pertanyaan yang ingin dicarikan jawaban secara mendalam meliputi: Bagaimana strategi guru kelas dalam meningkatkan literasi media pembelajaran di tengah pendemi Covid-19?, Apa saja media pembelajaran yang digunakan guru kelas di masa pandemi Covid-19?, dan, apa saja kendala yang di alami guru kelas dalam peningkatan literasi media pembelajaran di masa pandemi Covid-19?. Riset ini lebih menekankan pada dua lembaga pendidikan dasar (Madrasah Ibtidaiyah) dengan titik fokus pada Madrasah Ibtidaiyah berdiri ditengah perkotaan dan perdesaan.

\section{B. METODE PENELITIAN}

Penelitian ini menggunakan metode kualitatif dengan pendekatan studi kasus yaitu melihat latar ilmiah sebuah kasus yang terjadi di lapangan khususnya tentang strategi guru kelas dalam meningkatkan literasi media pembelajaran di masa pandemi Covid-19. Penelitian dilakukan di dua lokasi yang memiliki karakteristik berbeda, yaitu Madrasah Ibtidaiyah Al-Azhar Menganti Gresik, sebagai salah satu madrasah yang berdiri di tengah perkotaan tepatnya di Kota Gresik bagian selatan, dan Madrasah Ibtidaiyah An-Nur Plus Junwangi Sidoarjo, sebagai salah satu madrasah ibtidaiyah yang berdiri di tengah pedesaan. Kedua madrasah ibtidaiyah tersebut cukup diminati oleh masyarakat sekitarnya.

Sumber data primer dalam penelitian ini adalah seluruh guru kelas, sedangkan data sekunder meliputi seluruh elemen yang masuk pada Madrasah Ibtidaiyah AlAzhar Menganti Gresik dan Madrasah Ibtidaiyah An-Nur Junwangi Sidoarjo. Teknik pengumpulan data menggunakan observasi nonpartisipatif, wawancara semi terstruktur, dan dokumentasi. Analisis data mengguanakan model interaktif yang dikembangkan Miles dan Hubarman (Miles et al., 2014) yang meliputi pengumpulan data, reduksi data, penyajian data, dan penarikan kesimpulan. Untuk menjaga kredibilitas hasil penelitian, peneliti menggunakan uji keabsahan data yang disampaikan oleh Quin Patton yaitu triangulasi, meliputi triangulasi teknik, triangulasi sumber dan triangulasi teori. 


\section{HASIL DAN PEMBAHASAN}

1. Hasil

\section{a. Strategi Guru Kelas dalam Meningkatkan Literasi Media Pembelajaran di Masa} Pendemi Covid-19

Literasi media pembelajaran bagi guru kelas adalah sebuah kewajiban, terlebih pada masa pandemi Covid-19. Literasi media menjadi salah satu indikator dari guru profesional, tepatnya pada kompetensi pedagogik guru. Selain itu, guru kelas pada sekolah dasar (Madrasah Ibtidaiyah) lebih banyak mempunyai tanggung jawab terhadap siswa pada kelas masing-masing. Sebagaimana hasil yang didapatkan peneliti di lapangan tentang beberapa cara guru kelas dalam meningkatkan literasi media pembelajaran di tengah pandemi Covid-19. Guru kelas di Madrasah Ibtidaiyah AlAzhar Menganti Gresik, mempunyai beberapa terobosan dalam meningkatkan literasi media pembelajaran. BR, selaku guru kelas mempunyai beberapa cara dalam meningkatkan literasi media pembelajaran, secara individu seperti: mengikuti webinar virtual yang diadakan oleh beberapa perguruan tinggi, mulai dari pemilihan media yang tepat di masa pembelajaran online. Selain itu, guru kelas memanfaatkan teknologi informasi, dari membaca media online, blogspot, website dan media Youtube yang bertransformasi menjadi media pembelajaran dan sebagai sumber belajar guru. Selain itu, guru kelas membiasakan mengikuti perkembangan hasil penelitian dengan membaca artikel-artikel yang diterbitkan oleh jurnal nasional dan internasional, dengan subjek penelitian media yang tepat di tengah pendemi Covid-19. Selain secara individu, guru kelas meningkatkan literasi media pembelajaran melalui agenda dari madrasah berupa pelatihan media pembelajaran berupa media Canva.

Pernyataan di atas, juga disampaikan oleh DA yang notabenya adalah guru kelas IV, menjelaskan tentang peningkatan secara individu melalui memperbayak membaca artikel jurnal yang terdapat pada google scholar, karena di dalam google scholar para individu dapat mengetahui media yang tepat dan banyak digunakan pada zona nasional maupun internasional. Selain itu DA meningkatkan literasi media pembelajaran melalui intruksi dari lembaga. Kepala sekolah memberikan agenda khusus untuk guru dalam memilih media pembelajaran. Berdasarkan beberapa penjelasan di atas, FS selaku guru kelas meningkatkan literasi media melalui pemanfaatan teknologi berupa menguatkan jejaring dengan melihat perkembangan yang terjadi di media elektronik. Selain pemanfaatan teknologi, guru kelas meningkatkan media literasi melalui pelatihan yang di adakan oleh Lembaga berupa pelatihan media Canva dalam proses pembelajaran. Beberapa pernyataan di atas, juga disampaikan oleh FS sebagai guru kelas dalam meningkatkan literasi media dengan mengikuti kegiatan yang diadakan oleh pihak lembaga Madrasah Ibtidaiyah secara online maupun offline. Sedangkan dalam meningkat kompetensi di era pandemi, secara pribadi banyak memanfaatkan webinar, seminar online yang menjamur dan gratis di tengah pandemi Covid-19. Selain itu manfaat dari Whatsapp grup guru ma'arif dapat membantu, karena saling memberikan info tentang media yang tepat digunakan dalam pembelajaran.

Selain pemaparan guru kelas lembaga Madrasah Ibtidaiyah Al-Azhar Menganti. Guru kelas pada Madrasah Ibtidaiyah An-Nur Junwangi, mempunyai karakter yang cukup berbeda dalam strategi meningkatkan literasi media pembelajaran di masa pandemi Covid-19. Hal ini dipaparkan oleh HK selaku guru kelas di Madrasah

Vol. 13 No. 2 Juni 2021

Madrasah homepage: http://ejournal.uin-malang.ac.id/index.php/Madrasah/index 
Ibtidaiyah An-Nur Junwangi, yaitu dalam proses peningkatan literasi media pembelajaran cenderung termotivasi secara individu dengan mengikuti webinar berbasis Zoom tentang kesuksesan pembelajaran di masa pandemi, selain itu guru memanfaatkan media elektronik seperti Youtube, dalam mengoperasikan dan mencari tahu tentang pemanfaatan media sosial, seperti Whatsapp, Youtube, Google Meet dan Zoom.

Hal senada disampaikan oleh KR, bahwa dalam meningkatkan literasi media adalah dengan mengikuti perkembangan pada media online. Hal ini menjadi satusatunya solusi karena di masa pendemi tidak diperbolehkan melakukan kegiatan yang bersifat mengundang banyak masa. Maka secara individu KR memilih untuk mencari media pembelajaran yang tepat dengan memanfaatkan google. Pemaparan tersebut di benaran oleh JS yang menjadi guru kelas, bahwa secara individu dalam proses meningkatkan literasi media pembelajaran di masa pandemi adalah dengan mengikuti perkembangan media baik online maupun elektronik, seperti pembelajaran di dalam Televisi. Namun, guru juga mengikuti seminar online dengan media Zoom di beberapa kesempatan, dengan tujuan dapat menunjang pada kebutuhan dari proses pembelajaran.

\section{b. Media Pembelajaran Guru Kelas}

Keberadaan guru dalam proses meningkatkan literasi media pembelajaran mendorong pemilihan varian media yang digunakan dalam proses pembelajaran online. Selain itu pemanfaatan media yang bervariasi berimbas pada minimalisasi kejenuhan pada diri seorang siswa. Hal ini juga dapat dilihat dari beberapa varian media yang digunakan oleh guru kelas di Madrasah Ibtidaiyah Al-Azhar Menganti Gresik. Sebagaimana yang disampaikan oleh BR tentang beberapa media yang sudah digunakan dalam proses pembelajaran di masa pandemi yang sudah hampir 1 tahun, beberapa media pembelajaran yang sudah dipraktikkan oleh BR, mulai dari media Youtube, sebagai salah satu media yang sangat familiar digunakan oleh siswa di tingkat sekolah dasar, media Youtube tidak berdiri sendiri melainkan metode ini digunakan bergantian dengan media Whatsapp Group (WAG), sebagai media penghubung kepada seluruh siswa dan wali siswa. Mulai dari pengiriman link pembelajaran sampai proses dan evaluasi pembelajaran. Media Zoom, juga menjadi media pilihan guru kelas, karena Zoom lebih familiar digunakan dalam proses pembelajaran di masa pandemi Covid-19. Selain ketiga media di atas, BR menggunakan media pembelajaran berupa Google Meet dan Canva sebagai salah satu media terbaru dan lebih efektif sehingga memberikan ruang pengetahuan baru bagi para siswa dalam mengeksplor pengetahuan.

Beberapa media pembelajaran di atas, juga dipakai oleh DA yang merupakan guru kelas di Madrasah Ibtidaiyah Al-Azhar Menganti Gresik, pada saat pembelajaran online lebih banyak memanfaatkan media Whatsapp Grup sebagai salah satu media yang multi guna dan dimiliki oleh seluruh siswa. Selain Whatsapp media lain yang digunakan adalah media Google Meet, Zoom dan Youtube dikarenakan dua aplikasi ini adalah aplikasi yang terpasang langsung dengan smartphone masing-masing siswa. Hal ini juga di sampaikan oleh FS tentang media pembelajaran yang di gunakan pada masa pandemi Covid-19, yaitu menggunakan Whatsapp Grup dalam membagikan link 
Youtube. Jadi, secara praktik media yang digunakan adalah aplikasi Youtube karena dapat dilakukan pemutaran berulang jika terjadi ketidak fahaman dalam materi pembelajaran. Selain itu FS juga menggunakan media Benime sebagai media yang kurang familiar namun cukup dapat dimaksimalkan dalam proses pembelajaran.

Gambar C. 1 Media Pembelajaran Guru Kelas di Madrasah Ibtidaiyah Al-Azhar Menganti Gresik

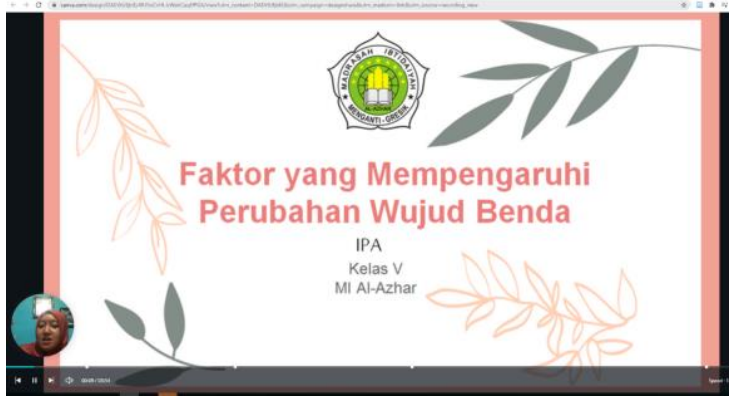

Pembelajaran dengan Media Canva

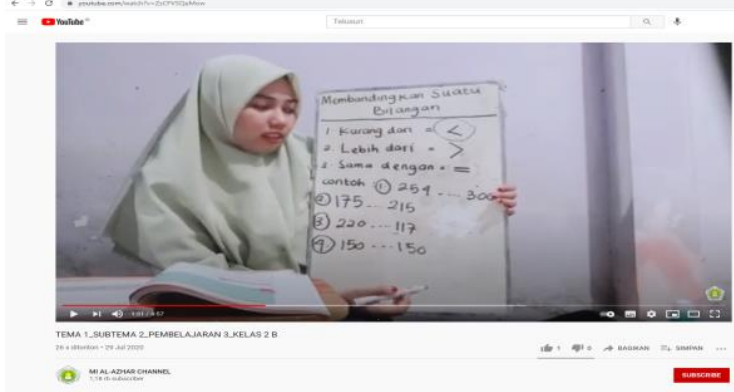

Pembelajaran dengan Media Youtube

Pemaparan yang cukup berbeda didapatkan dari hasil wawancara dan observasi di Madrasah Ibtidaiyah An-Nur Desa Junwangi Sidoarjo, tentang beberapa media yang digunakan guru dalam proses pembelajaran. Sebagaimana yang disampaikan oleh HK, tentang beberapa media pembelajaran yang digunakan guru kelas dalam pembelajaran yaitu Whatsapp Grup berupa voice note, hal ini mencoba dimaksimalkan seluruh guru dikarenakan di pedesaan mempunyai beberapa kendala, mulai dari SDM sampai paket data internet. Meskipun pada awal pandemi yang terjadi di Indonesia sempat 1-2 kali melakukan pembelajaran menggunakan media Youtube dan Zoom. Namun, tidak dapat berjalan secara continue. Selain pemaparan di atas KR selaku guru kelas, memberikan penjelasan tentang media yang digunakan hanya pada memanfaatkan media Whatsapp Grup, pemilihan ini berdasaran rekomendasi dan keluhan yang disampaikan wali siswa kepada Madrasah Ibtidaiyah An-Nur Junwangi Sidoarjo. Keadaan demikian juga disampaikan JS, bahwa selama masa pendemi Covid-19, media yang digunakan hampir tidak ada pergeseran dari pemaksimalan Whatsapp, mengingat banyaknya kendala di Madrasah Ibtidaiyah pedesaan dan minimnya pemahaman tentang media pembelajaran lainnya. JS membenarkan yang telah disampaikan oleh HK tentang adanya percobaan menggunakan media pembelajaran Zoom, Google Meet dan Youtube. Namun, hanya berlaku 1-2 kali pertemuan. Dari beberpa hasil wawancara di Madrasah Ibtidaiyah An-Nur Junwangi Sidoarjo, dapat diambil kesimpulan bahwa media yang digunakan guru kelas adalah Whatsapp Grup kelas (WAG).

\section{c. Kendala Guru Kelas Dalam Meningkatkan Literasi Media Pembelajaran}

Berdasarkan pembahasan media di atas, tidak menutup kemungkinan adanya kendala-kendala yang terjadi pada guru kelas dalam meningkatkan literasi media di masa pandemi Covid-19. Posisi literasi media menjadi salah satu indikator dari kompetensi pedagogik. Sebagaimana pemaparan BR, yang menjadi kendala guru kelas

Vol. 13 No. 2 Juni 2021

Madrasah homepage: http://ejournal.uin-malang.ac.id/index.php/Madrasah/index 
dalam proses meningkatkan literasi media pembelajaran adalah faktor sarana prasarana meliputi smartphone yang cenderung masih standar, sehingga sering terjadinya eror. Selain faktor smartphone masalah yang perlu penyelesaian adalah kuota internet, pemaksimalan kuota karena setiap mengikuti pelatihan yang berbasis webinar dan pemanfaatan internet, posisi kuota menjadi paling utama. Meskipun pihak Madrasah Ibtidaiyah memberikan solusi dengan pemasangan saluran wifi. Namun ketika work from home tidak semua guru memasang wifi di rumah masing-masing.

Pemaparan di atas juga di sampaikan DA, sebagai guru kelas dan pelaku proses peningkatan literasi media pembelajaran di masa Covid-19, yang semuanya tergantung pada pribadi guru. Pada masa pandemi seluruh pelatihan dan seminar terbilang sangatlah banyak. Kendala utama adalah kouta internet cepat habis. Pada dasarnya pihak Madrasah menyiapkan solusi berupa melakukan pelatihan secara mandiri dan bergelombang (3-4 guru kelas), disertai dengan penerapan protokol kesehatan yang sangat ketat. FS menjelaskan demikian tentang kendala dalam proses meningkatkan literasi media pembelajaran yang paling utama adalah kondisi smartphone dan laptop masih di bawah standar sehingga kurang dapat mengikuti secara maksimal, selain kondisi smartphone dan laptop yaitu kondisi paket data internet, hal ini menjadi keluhan dari setiap guru kelas ketika mengikuti pelatihan melalui media online, seperti Zoom, Google Meet dan Youtube. Namun, hal tersebut bisa teratasi jika ke Madrasah, karena terfasilitasi dengan jaringan wifi, selain itu pihak Madrasah mencoba memberikan pelatihan mandiri dengan bergiliran agar para guru dapat meningkatkan kompetensi literasi media meskipun di tengah pandemi Covid-19. Perhatian khusus diberikan pihak lembaga, dikarenakan posisi pembelajaran yang membosankan dan monoton dapat menimbulkan kemalasan pada diri siswa.

Kendala demikian juga terjadi pada guru kelas pada Madrasah Ibtidaiyah AnNur Junwangi Sidorjo, yang merupakan Madrasah di pedesaan. Sebagaimana penuturan $\mathrm{HK}$, tentang kendala yang dialami dalam meningkatkan literasi media pembelajaran di masa pandemi Covid-19, yakni berupa keadaan jaringan internet yang kurang mendukung dan kuota internet yang cukup menjadi beban para guru kelas, selain jaringan dan kuota smartphone juga menjadi kendala. Namun, dalam mengatasi kendala-kendala di atas guru mencoba terus mencari informasi melalui Whatsapp Grup guru. Keadaan senada juga dialami oleh KR, tentang kuota internet yang cukup menguras kantong. Namun, selain kuota internet keberadaan smartphone yang perlu di standartkan juga menjadi harapan dari seluruh guru kelas. JS membenarkan tentang kendala yang dialami guru kelas dalam meningkatkan literasi media pembelajaran adalah smartphone yang masih sangat standart dan laptop juga masih perlu upgrading. Selain dua kendala di atas adalah posisi kouta internet yang tetap menjadi kendala utama.

\section{Pembahasan}

a. Peningkatkan Literasi Media Pembelajaran Guru Kelas di Masa Pendemi Covid19

Masa pandemi Covid-19 dunia pendidikan mengalami transformasi yang cukup signifikan (Mansyur, 2020) terutama dalam hal penggunaan teknologi informasi bagi guru, posisi pemanfaatan teknologi menjadi sebuah kewajiban bagi guru agar dapat

Vol. 13 No. 2 Juni 2021

Madrasah homepage: http://ejournal.uin-malang.ac.id/index.php/Madrasah/index 
memaksimalkan proses pembelajaran (Van Bommel et al., 2020). Selain itu, Destina, Utami dan Darma, menyatakan bahwa guru yang dapat memanfaatkan media pembelajaran berbasis teknologi menjadi salah satu indikator guru yang memiliki kompetensi pedagogik sehingga dapat di kategorikan guru profesioonal. (Destiana \& Utami, 2017) (Darma, 2018) Dewi dan Syah juga menyampaikan pada risetnya tentang dampak yang terjadi dalam dunia pendidikan, salah satunya adalah proses belajarmengajar dengan melalui sistem online, sehingga guru diharapkan melakukan lompatan-lompatan kreatif (Dewi, 2020), (Syah, 2020). Hal senada disampaikan Basri dkk, bahwa, pemanfaatan teknologi melalui media online dalam proses pembelajaran terbilang cukup efektif digunakan guru dalam meningkatkan literasi media pada masa pandemi Covid-19 (Basri et al., 2020). Sehingga, adanya perkembangan dunia teknologi pada sektor pendidikan semakin menjadikan guru sebagai solusi terbaik dan mampu menjawab tantangan di masa depan (Ally, 2019) Maka, keadaan ini di respon guru kelas di Madrasah Ibtidaiyah Al-Azhar Menganti Gresik dan Madrasah Ibtidaiyah AnNur Junwangi Sidoarjo dengan tetap melakukan peningkatan literasi media melalui dua alur, meliputi; pertama, peningkatan secara individu dan kedua, peningkatan secara kelembagaan. Hal tersebut juga disampaikan Arif dari hasil risetnya, bahwa guru meningkatkan kompetensi melalui dua alur, pertama individu dana kedua adalah kelembagaan (Arif, 2018).

Pertama, peningkatan secara individu yaitu dengan memaksimalkan dalam mengikuti pelatihan dan webinar secara virtual, peningkatan ini dilakukan guru kelas pada kedua lembaga, yaitu Madrasah Ibtidiayah Al-Azhar Menganti Gresik dan Madrasah Ibtidaiyah An-Nur Junwangi Sidoarjo. Dari fakta demikian maka sudah sepatutnya guru kelas dapat memaksimalkan dunia teknologi untuk belajar-mengajar di era digital (Siyamitri, 2015) Karena hanya dengan teknologi peningkatan kompetensi guru kelas di masa pandemi Covid-19 dapat terus berjalan secara continue (Yusrizal et al., 2017). Keberadaan Beberapa media pembelajaran yang berhubungan langsung dengan pemanfaatan teknologi di masa kini, seperti aplikasi Zoom, sebagaimana Basri, dkk mengungkap bahwa Zoom menjadi salah satu media yang efektif di gunakan dalam proses belajar, mulai dari adanya webinar, workshop dan beberapa kegiatan lainnya, sehingga guru tetap dapat meningkatkan literasi media di masa pandemi Covid-19 (Basri et al., 2020) selain itu, media yang digunakan guru kelas dalam mengikuti webinar pendidikan adalah Google Meet (Susanti \& Prameswari, 2020) karena, kebanyakan para akademisi membuat pelatihan dan webinar berbasis media Google Meet sehingga guru kelas wajib mengikuti setiap proses peningkatan literasi media pembelajaran di masa pandemi Covid-19 (Nursiyanto et al., 2020).

Selain media di atas, beberapa guru kelas di Madrasah Ibtidaiyah Al-Azhar Menganti Gresik dan Madrasah Ibtidaiyah An-Nur Junwangi Sidoarjo. Dalam meningkatkan literasi media melalui media online dan media sosial, mulai dari website kementrian pendidikan tentang update pendidikan di masa pandemi Covid-19, blogspot, sebagaimana Rohmawati dkk menjelaskan bahwa belajar melalui media website cukup tepat serta mendapatkan respon positif untuk meningkatkan literasi. (Rohmawati et al., 2018), hal senada juga di sampaikan Chawinga, bahwa website dan blog menjadi salah satu media belajar yang cukup efektif (Chawinga, 2017) selain media di atas juga terdapat media Youtube sebagai salah satu media belajar yang digunakan guru kelas, Youtube menjadi salah satu media yang sangat familiar dan

Vol. 13 No. 2 Juni 2021

Madrasah homepage: http://ejournal.uin-malang.ac.id/index.php/Madrasah/index 
mempunyai banyak peminat, mulai dari balita hingga dewasa (Jaffar, 2012) Selain itu banyaknya praktisi pendidikan memberikan pemahaman tentang pendidikan secara tuntas melalui media Youtube (Susanti \& Prameswari, 2020) selain itu, literasi media yang digunakan guru kelas agar tetap dapat meningkatkan literasi media pembelajaran yang tepat pada masa pandemi Covid-19, yaitu melalui Whatsapp Grup (WAG) guru. Hal ini disebutkan Astini, tentang banyaknya pemilih bagi pengguna dalam pemanfaatan Whatsapp di masa Covid-19 (Astini, 2020). Hal ini menunjukkan tentang pentingnya seluruh media teknologi digunakan untuk memaksimalkan seluruh proses pembelajaran.

Selain beberapa terobosan yang sudah dilakukan guru kelas dalam proses peningkatan literasi media pembelajaran di masa pandemi Covid-19. Terdapat salah satu keunikan yang dilakukan guru kelas di Madrasah Ibtidaiyah Al-Azhar Menganti Gresik, yang merupakan Madrasah dengan dominasi guru berpredikat lulusan fresh graduate. Sehingga guru kelas dalam pemaksimalan meningkatkan literasi media pembelajaran, melalui membaca informasi berbasis artikel nasional dan internasional tentang media pembelajaran yang tepat untuk proses pembelajaran di masa pandemi Covid-19. Hal ini telah disampaikan Pratte pada hasil risetnya, yaitu perlu adanya revolusi media pembelajaran pada dunia pendidikan (Pratte, 2020) salah satunya adalah posisi guru yang harus tetap belajar meskipun pada posisi keterbatasan. Selain peningkatan secara individual Madrasah Ibtidaiyah Al-Azhar Menganti Gresik juga melakukan peningkatan secara kelembagaan, yaitu dengan megikuti pelatihan secara bergilir yang diadakan pihak Madrasah Ibtidaiyah, berupa pemanfaatan media pembelajaran berbasis Canva di masa pandemi Covid-19. Media Canva, menjadi media yang cukup efektif dan mudah digunakan guru dalam proses pembelajaran (Pelangi, 2020).

\section{b. Media Pembelajaran Guru Kelas di Masa Pendemi Covid-19}

Media pembelajaran berbasis teknologi yang digunakan dalam proses belajarmengajar di masa pandemi Covid-19 sangatlah bervariasi (Pakpahan \& Fitriani, 2020) Hal ini merupakan imbas dari di tutupnya sekolah guna menghindari kerumunan agar mengurangi penyebaran Covid-19. Keadaan tersebut di alami oleh seluruh pemangku pendidikan mulai dari guru, siswa sampai orang tua. Merespon kejadian tersebut beberapa guru kelas memanfaatkan media berbasis teknologi yang sudah diperoleh dari berbagai informasi dan pelatihan sehingga dapat memaksimalkan pembelajaran online (Firman \& Rahayu, 2020). Hal tersebut juga disampaikan Ally, bahwa digitalisasi pada dunia pendidikan menjadi tantangan guru agar tetap mengikuti perkembangan agar proses pembelajaran dapat tersampaikan secara maksimal (Ally, 2019)

Menanggapi keadaan di atas, guru kelas pada Madrasah Ibtidaiyah Al-Azhar Menganti Gresik, dalam proses pembelajaran online dengan memaksimalkan media teknologi masa kini. Beberapa media pembelajaran yang di gunakan guru kelas, seperti media Zoom, salah satu media yang sangat familiar digunakan pada proses pembelajaran, selain penggunaan yang cukup praktis, media Zoom mempunyai fitur yang cukup lengkap (Febriyanti \& Sundari, 2020), selain itu Zoom menjadi media yang cukup favorit digunakan sehingga dapat membantu dalam proses pembelajaran online (Basri et al., 2020), karena pada media Zoom antara siswa dan guru dapat melakukan

Vol. 13 No. 2 Juni 2021

Madrasah homepage: http://ejournal.uin-malang.ac.id/index.php/Madrasah/index 
interaksi secara langsung, sehingga meminimalkan adanya kegagalan dalam memahami materi pembelajaran (Haqien \& Rahman, 2020)

Selain media Zoom, media yang digunakan adalah google meet, sebuah media pembelajaran yang mempunyai kemiripan dengan Zoom. Google Meet sampai saat ini masih free pada batas waktu penggunaan. Sehingga media Google Meet menjadi pilihan bagi guru dalam menyampaikan pembelajaran kepada siswa (Gupta \& Pathania, 2021). Pemilihan Google Meet sebagai salah satu media pembelajaran yang tepat. Beberapa fitur dan penggunaan dari Google Meet cukup simpel, sehingga memudahkan pemakainya (E. Purwanto \& Tannady, 2020). Sebagaimana hasil riset Susanti Prameswari menjelaskan bahwa pembelajaran Bahasa Inggris pada sekolah dasar menggunakan media Google Meet sangatlah membantu pembelajaran secara maksimal (Susanti \& Prameswari, 2020). Hal senada juga disampaikan Al-Maroof, dkk dalam risetnya, tentang keefektifan media Google Meet dalam proses pembelajaran, dikarenakan tergolong media yang sudah cukup di kenal oleh guru dan siswa serta cukup menghemat data seluler (Al-Maroof et al., 2020)

Selain Zoom dan Google Meet, peran media sosial yang menjadi alat komunikasi dapat di alih fungsikan sebagai media pembelajaran online, karena dengan keterbatasan proses belajar mengajar secara pertemuan langsung, maka solusi utama adalah dengan memaksimalkan media sosial dalam pembelajaran (Mart \& Campbell-Barr, 2020). Salah satu pilihan yang cukup familiar di gunakan guru selama pandemi Covid-19 yaitu Youtube (Mirbabaie et al., 2020) DeWitt dari hasil risetnya, telah menyampaikan bahwa media sosial Youtube menjadi salah satu media pilihan bagi guru di masa depan, (DeWitt, 2013), seiring dengan adanya pandemi Covid-19. Maka, media Youtube dijadikan media pembelajaran yang sangat efektif dalam proses belajar-mengajar di Madrasah (Sari et al., 2020), selain itu terdapat pula terobosan guru dalam melakukan proses pembelajaran dengan memadukan antara Google Meet dan Youtube dalam satu pembelajaran, atau lebih sering di kenal dengan blanded learning pada anak sekolah dasar (Susanti \& Prameswari, 2020). Selain media Youtube, guru pada Madrasah Ibtidaiyah Al-Azhar Menganti Gresik, melakukan pembelajaran dengan menggunakan media Canva, salah satu media pembelajaran yang memanjakan penggunanya dengan berbagai template yang menarik (Tanjung \& Faiza, 2019). Hal senada juga di sampaikan Pelangi dari risetnya dengan simpulan bahwa media Canva adalah media yang efektif digunakan guru dalam proses pembelajaran, selain media yang sangat elegan, Canva dapat memberikan pemandangan baru pada diri siswa, sehingga siswa terhindar dari bosan dalam proses pembelajaran (Pelangi, 2020).

Selain beberapa media yang telah disebutkan di atas, terdapat satu pilihan media yang sama untuk digunakan guru kelas dalam proses pembelajaran di Madrasah Ibtidaiyah Al-Azhar Menganti Gresik dan Madrasah Ibtidaiyah An-Nur Junwangi Sidoarjo, yaitu media Whatsapp, sebagaimana Youtube, Whatsapp juga berperan ganda. Selain menjadi media sosial, Whatsapp juga menjadi media pembelajaran yang cukup banyak dipilih guru dalam menyampaikan pembelajaran (Lestari, 2021) beberapa dasar pijakan pemilihan Whatsapp untuk proses pembelajaran adalah dalam penekanan kuota internet yang digunakan. Hasanah juga menyampaikan demikian bahwa keberadaan aplikasi Whatsapp tidak terlalu besar dalam pengambilan data seluler (Hasanah, 2020).

Vol. 13 No. 2 Juni 2021

Madrasah homepage: http://ejournal.uin-malang.ac.id/index.php/Madrasah/index 
Gambar C. 2 Proses Peningkatan Literasi Media Pembelajaran Guru Kelas
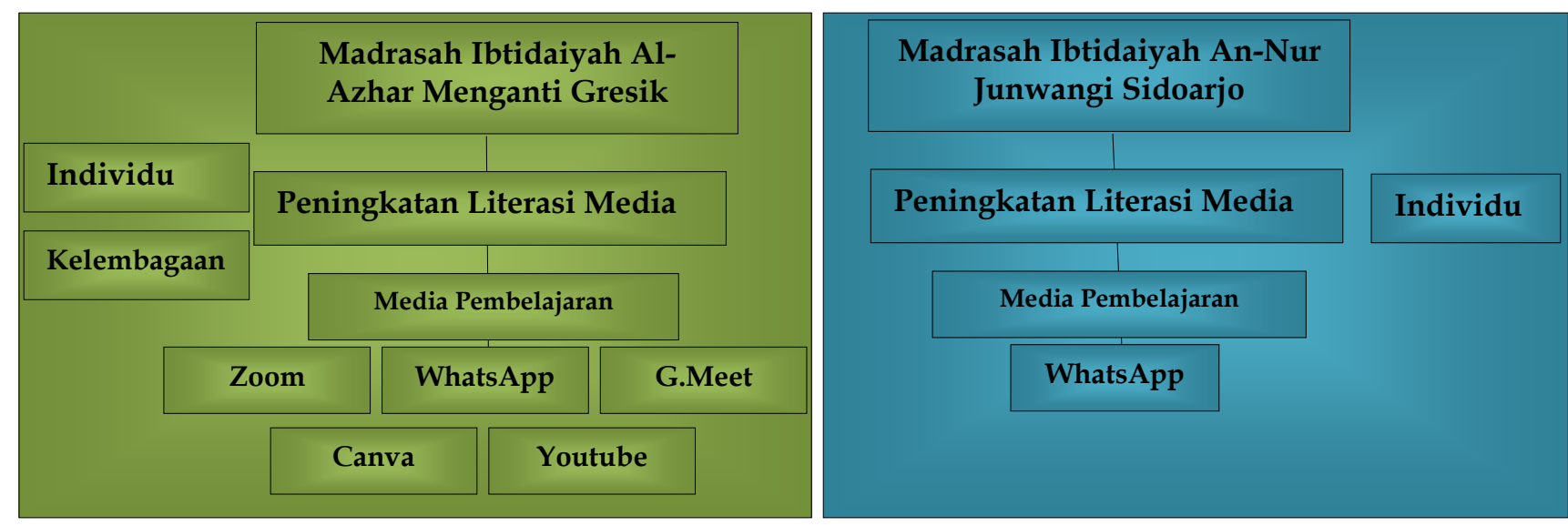

\section{c. Kendala Guru Kelas Dalam Peningkatan Literasi Media}

Keberadaan guru kelas dalam meningkatkan literasi media pembelajaran mengalami beberapa kendala (Firman \& Rahayu, 2020). Hal ini disampaikan oleh guru kelas pada Madrasah Ibtidaiyah Al-Azhar Menganti Gresik dan Madrasah Ibtidayah An-Nur Junwangi Sidoarjo, tentang beberapa kendala yang di alami guru kelas dalam proses peningkatan literasi media di masa pandemi Covid-19, meliputi: pertama, kuota internet yang diberikan kepada guru masih cukup terbatas, karena selain harus melaksanakan pembelajaran secara daring (Anugrahana, 2020), guru juga terus melakukan upgrading keilmuan dan pembelajaran yang menyenangkan. Terutama dalam mengikuti peningkatan literasi media dengan aplikasi Zoom, Google Meet dan beberapa media lainnya (Myori et al., 2019), sehingga memakan kuota internet begitu besar, hal ini juga di sampaikan Taradisa bahwa kendala guru adalah kuota internet (Taradisa et al., 2020). Hal ini perlahan diberikan solusi oleh Madrasah Ibtidaiyah AlAzhar Menganti Gresik, berupa pemasangan jaringan wifi, sehingga dapat mengurangi kendala guru.

Kedua, kendala yang dialami guru kelas dalam meningkatkan literasi media pembelajaran adalah fasilitas dari teknologi yang digunakan yaitu: smartphone yang masih standart, seperti smartphone dengan kapasitas Ram 1-2 Gigabyte, dan memori internal di bawah 46 Gigabyte, sehingga dapat mengganggu proses pembelajaran (Rigianti, 2020), keadaan ini terjadi karena kewajiban melakukan instalasi aplikasi, sehingga dapat mempersempit ruang penyimpanan di dalam smartphone (Agustin et al., 2020). Serta kendala pada laptop yang digunakan guru dalam proses mengikuti peningkatan literasi media yang masih di bawah rata-rata. Maka, perlu adanya peningkatan dari sarana yang digunakan oleh guru kelas (A. Purwanto et al., 2020) Sehingga proses peningkatan literasi media pembelajaran dapat berjalan secara maksimal, serta dapat diterapkan dalam proses belajar-mengajar secara online.

\section{KESIMPULAN}

Berdasarkan pemaparan di atas maka simpulan riset tentang peningkatan literasi media pembelajaran guru kelas pada Madrasah Ibtidaiyah Al-Azhar Menganti Gresik

Vol. 13 No. 2 Juni 2021

Madrasah homepage: http://ejournal.uin-malang.ac.id/index.php/Madrasah/index 
dan Madrasah Ibtidaiyah An-Nur Junwangi Sidoarjo di masa pandemi Covid-19 sebagai berikut: Pertama, peningkatan literasi media pembelajaran secara individu dengan mengikuti pelatihan media pembelajaran secara virtual menggunakan Zoom, Google Meet. Memaksimalkan media online (website dan blogspot) dan media sosial (Youtube dan Whatsapp Grup guru kelas). Namun, dalam peningkatan guru kelas secara individu, Madrasah Ibtidaiyah Al-Azhar Menganti Gresik, memaksimalkan membaca artikel/jurnal nasional dan internasional tentang media pembelajaran yang efektif digunakan pada masa pandemi Covid-19. Selain secara individu Madrasah Ibtidaiyah Al-Azhar Menganti Gresik, memberikan peningkatan secara kelembagaan berupa pelatihan media canva dengan protokoler kesehatan yang maksimal. Kedua, Media pembelajaran yang digunakan guru kelas di Madrasah Ibtidaiyah Al-Azhar Menganti Gresik, meliputi: Zoom, Google Meet, Canva, Youtube dan Whatsapp. Sedangkan guru kelas pada Madrasah Ibtidaiyah An-Nur Junwangi Sidoarjo dalam melaksanakan pembelajaran menggunakan grup Whatsapp. Ketiga, kendala guru kelas di Madrasah Ibtidaiyah Al-Azhar Menganti Gresik dan Madrasah Ibtidaiyah An-Nur Junwangi Sidoarjo dalam meningkatkan literasi media pembelajaran di masa pandemi Covid-19 meliputi: borosnya kuota internet, sarana berupa media elektronik smartphone dan laptop yang masih standar sehingga perlu peningkatan.

\section{E. REFERENSI}

Agustin, M., Puspita, R. D., Nurinten, D., \& Nafiqoh, H. (2020). Tipikal Kendala Guru PAUD dalam Mengajar pada Masa Pandemi Covid 19 dan Implikasinya. Jurnal Obsesi: Jurnal Pendidikan Anak Usia Dini, 5(1), 334-345. https://doi.org/10.31004/obsesi.v5i1.598

Ally, M. (2019). Competency Profile of the Digital and Online Teacher in Future Education. International Review of Research in Open and Distributed Learning, 20(2), 303-319.

Al-Maroof, R. S., Salloum, S. A., Hassanien, A. E., \& Shaalan, K. (2020). Fear from COVID-19 and technology adoption: The impact of Google Meet during Coronavirus pandemic. Interactive Learning Environments, 1-16. https:/ / doi.org/10.1080/10494820.2020.1830121

Anugrahana, A. (2020). Hambatan, Solusi dan Harapan: Pembelajaran Daring Selama Masa Pandemi Covid-19 Oleh Guru Sekolah Dasar. Scholaria: Jurnal Pendidikan dan Kebudayaan, 10(3), 282-289. https://doi.org/10.24246/j.js.2020.v10.i3.p282289

Arif, M. (2018). Peningkatan Kompetensi Pedagogik Dan Profesional Guru Kelas Madrasah Ibtidaiyah Di Kabupaten Gresik (Studi Multi Kasus di Madrasah Ibtidaiyah Plus Riyadlatul Athfal Hulaan Menganti dan Madrasah Ibtidaiyah Mamba'us Sholihin Suci Manyar). UIN Sunan Ampel Surabaya.

Arif, M., Mulyadi, M., Bahrozi, I., \& Hudah, N. (2020). Madrasah Ibtidaiyah Transformation Based on Pesantren in the Era of Industrial Revolution 4.0. Psychology and Education, 57(8), 420-435.

Arif, M., \& Sulistianah, S. (2019). Problems in 2013 Curriculum Implementation for Classroom Teachers in Madrasah Ibtidaiyah. Al Ibtida: Jurnal Pendidikan Guru MI, 6(1), 110. https://doi.org/10.24235/al.ibtida.snj.v6i1.3916

Vol. 13 No. 2 Juni 2021

Madrasah homepage: http://ejournal.uin-malang.ac.id/index.php/Madrasah/index 
Astini, N. K. S. (2020). Tantangan Dan Peluang Pemanfaatan Teknologi Informasi Dalam Pembelajaran Online Masa Covid-19. Cetta: Jurnal Ilmu Pendidikan, 3(2), 241-255.

Basri, H., Sa'diyah, L. F., Khasanah, S. N., \& Hilmi, D. (2020). Efektivitas Pemanfaatan Media Online Dalam Pembelajaran Di Masa Pandemi Covid-19. Tarbiyatuna: Jurnal Pendidikan Ilmiah, 5(2), 145-158.

Chawinga, W. D. (2017). Taking social media to a university classroom: Teaching and learning using Twitter and blogs. 19.

Dabbagh, N. (2003). Scaffolding: An important teacher competency in online learning. TechTrends, 47(2), 39-44. https:/ / doi.org/10.1007/BF02763424

Darma, A. (2018). Perilaku Profesional Guru Progresif. POTENSIA: Jurnal Kependidikan Islam, 3(2), 143. https:/ / doi.org/10.24014/ potensia.v3i2.3891

Destiana, B., \& Utami, P. (2017). Urgensi Kompetensi Pedagogik Guru Vokasional Pada Pembelajaran Abad 21. Elinvo (Electronics, Informatics, and Vocational Education), 2(2), 211-222. https:// doi.org/10.21831/elinvo.v2i2.17368

Dewi, W. A. F. (2020). Dampak COVID-19 terhadap Implementasi Pembelajaran Daring di Sekolah Dasar. EDUKATIF: JURNAL ILMU PENDIDIKAN, 2(1), 55-61. https://doi.org/10.31004/edukatif.v2i1.89

DeWitt, D. (2013). The Potential of Youtube for Teaching and Learning in the Performing Arts. 9.

Febriyanti, R. H., \& Sundari, H. (2020). Platform for Application of Use in Online English Based Teaching. 2(1), 11.

Firman, F., \& Rahayu, S. (2020). Pembelajaran Online di Tengah Pandemi Covid-19. Indonesian Journal of Educational Science (IJES), 2(2), 81-89. https:/ / doi.org/10.31605/ijes.v2i2.659

Gupta, A., \& Pathania, P. (2021). To study the impact of Google Classroom as a platform of learning and collaboration at the teacher education level. Education and Information Technologies, 26(1), 843-857. https://doi.org/10.1007/s10639-02010294-1

Haqien, D., \& Rahman, A. A. (2020). Pemanfaatan Zoom Meeting untuk Proses Pembelajaran pada Masa Pandemi Covid-19. SAP (Susunan Artikel Pendidikan), 5(1). https:/ / doi.org/10.30998/sap.v5i1.6511

Hasanah, Q. (2020). Pemanfaatan Aplikasi Whastapp sebagai Media E-Learning Masa Covid19 pada Mata Kuliah Biomolekul dan Metabolisme di Tadris IPA IAIN Bengkulu. 1(3), 12.

Hurlbut, A. R. (2018). Online vs. Traditional learning in teacher education: A comparison of student progress. AMERICAN JOURNAL OF DISTANCE EDUCATION, 32(4), 248-266. https:// doi.org/10.1080/08923647.2018.1509265

Jaffar, A. A. (2012). Youtube: An emerging tool in anatomy education. Anatomical Sciences Education, 5(3), 158-164. https:/ / doi.org/10.1002/ase.1268

Kim, J. (2020). Learning and Teaching Online During Covid-19: Experiences of Student Teachers in an Early Childhood Education Practicum. IJEC, 52, 145-158. https:/ / doi.org/10.1007/s13158-020-00272-6 
Korhonen, A. M., Suhalahti, S., \& Veermans, M. (2018). The online learning process and scaffolding in student teachers' personal learning environments. Education and Information Technologies, 1-25. https:/ / doi.org/10.1007/s10639-018-9793-4

Lestari, W. (2021). Pemanfaatan Whatsapp Sebagai Media Pembelajaran Dalam Jaringan Masa Pandemi Covid-19 Di Kelas VI Sekolah Dasar. Universitas Jambi.

Malawi, I., Kadarwati, A., \& Dayu, D. P. K. (2018). Pembaharuan Pembelajaran di Sekolah Dasar. AE Media Grafika.

Mansyur, A. R. (2020). Dampak COVID-19 Terhadap Dinamika Pembelajaran Di Indonesia. Education and Learning Journal, 1(2), 113-123.

Mart, M., \& Campbell-Barr, V. (2020). Professional development opportunities for early years teachers using social media: The case of England and Turkey. Education 313, 1-16. https://doi.org/10.1080/03004279.2020.1734041

Miles, Mattew. B., Hubarman, A. M., \& Saldana, J. (2014). Qualitative Data Analiysis A Metode Sourcebook Edition 3. Sage.

Mirbabaie, M., Bunker, D., Stieglitz, S., Marx, J., \& Ehnis, C. (2020). Social media in times of crisis: Learning from Hurricane Harvey for the coronavirus disease 2019 pandemic response. Journal of Information Technology, 1-19.

Myori, D. E., Hidayat, R., Eliza, F., \& Fadli, R. (2019). Peningkatan Kompetensi Guru dalam Penguasaan Teknologi Informasi dan Komunikasi melalui Pelatihan Pengembangan Media Pembelajaran Berbasis Android. JTEV: Jurnal Teknik Elktro dan Vokasional, 5(2), 102-109.

Nugraha, Moh. F., Hendrawan, B., Pratiwi, A. S., \& Permana, R. (2020). Pengantar Pendidikan dan Pembelajaran di Sekolah Dasar. Edu Publisher.

Nursiyanto, N., Indera, I., Wibasuri, A., Lestari, S., \& Aziz, R. A. (2020). Pendampingan Media Pembelajaran Online Bagi Guru-Guru Sekolah Dasar Islam Pelangi Bandar Lampung. Seminar Nasional Hasil Penelitian dan Pengabdian 2020, 20-24.

Pakpahan, R., \& Fitriani, Y. (2020). Analisa Pemanfaatan Teknologi Informasi Dalam Pembelajaran Jarak Jauh Di Tengah Pandemi Virus Corona Covid-19. 4, 7.

Pelangi, G. (2020). Pemanfaatan Aplikasi Canva Sebagai Media Pembelajaran Bahasa Dan Sastra Indonesia Jenjang Sma/Ma. 8(2), 18.

Pratte, R. (2020). Media Revolution: Its Educational Implications. The Clearing House: A Journal of Educational Strategies, Issues and Ideas, 93(4), 207-211. https:/ / doi.org/10.1080/00098655.2020.1762415

Purwanto, A., Pramono, R., Asbari, M., Santoso, P. B., Mayesti, L., Hyun, C. C., \& Putri, R. S. (2020). Studi Eksploratif Dampak Pandemi COVID-19 Terhadap Proses Pembelajaran Online di Sekolah Dasar. EduPsyCouns Journal: Journal of Education, Psychology and Counseling, 2(1), 12.

Purwanto, E., \& Tannady, H. (2020). The Factors Affecting Intention to Use Google Meet Amid Online Meeting Platforms Competition in Indonesia. 62 (06), 10.

Rigianti, H. A. (2020). Kendala Pembelajaran Daring Guru Sekolah Dasar Di Kabupaten Banjarnegara. Elmentary School, 7(2), 297-302.

Rohmawati, E., Widodo, W., \& Agustini, R. (2018). Membangun Kemampuan Literasi Sains Siswa Melalui Pembelajaran Berkonteks Socio-Scientific Issues Berbantuan Media Weblog. Jurnal Penelitian Pendidikan IPA, 3(1), 8. https:/ / doi.org/10.26740/jppipa.v3n1.p8-14

Vol. 13 No. 2 Juni 2021

Madrasah homepage: http://ejournal.uin-malang.ac.id/index.php/Madrasah/index 
Sari, W. N., Samosir, B. S., Sahara, N., Agustina, L., \& Anita, Y. (2020). Learning Mathematics "Asyik" with Youtube Educative Media. Journal of Physics: Conference Series, 1477, 022012. https://doi.org/10.1088/1742$6596 / 1477 / 2 / 022012$

Siyamitri, P. (2015). Literasi Media Internet pada Kalangan Guru Sekolah Menengah Kejuruan di Kota Medan. Jurnal Simbolika, 1(2), 161-176.

Susanti, D. I., \& Prameswari, J. Y. (2020). Adaptasi Blended Learning di Masa Pandemi COVID-19 untuk Pembelajaran Bahasa Inggris di Sekolah Dasar. Jurnal: Lingua Susatra, 1(2), 50-61.

Syah, R. H. (2020). Dampak Covid-19 pada Pendidikan di Indonesia: Sekolah, Keterampilan, dan Proses Pembelajaran. SALAM: Jurnal Sosial dan Budaya Syar-i, 7(5). https:/ / doi.org/10.15408/sjsbs.v7i5.15314

Tanjung, R. E., \& Faiza, D. (2019). Canva Sebagai Media Pembelajaran Pada Mata Pelajaran Dasar Listrik Dan Elektronika. Voteknika: Jurnal Vokasi Teknik Elektronika dan Informatika, 7(2), 79-85.

Taradisa, N., Jarmita, N., \& Emalfida. (2020). Kendala yang dihadapi Guru Mengajar Daring Pad Masa Pndemi Covid-19 di MIN 5 Banda Aceh. UIN Ar-Raniry Banda Aceh.

Van Bommel, J., Randahl, A.-C., Liljekvist, Y., \& Ruthven, K. (2020). Tracing teachers' transformation of knowledge in social media. Teaching and Teacher Education, 87, 102958. https:/ / doi.org/10.1016/j.tate.2019.102958

Xue, S. (2019). Building an online community of practice through WeChat for teacher professional learning. Professional Development in Education, 1-26. https:/ / doi.org/10.1080/19415257.2019.1647273

Yusrizal, Y., Safiah, I., \& Nurhaidah, N. (2017). Kompetensi Guru Dalam Memanfaatkan Media Pembelajaran Berbasis Teknologi Informasi Dan Komunikasi (TIK) di SD Negeri 16 Banda Aceh. 2(2), 126-134. 